\title{
Insurance Companies in Emerging Markets
}

Janet Kong and Manmohan Singh 


\author{
IMF Working Paper \\ International Capital Markets Department \\ Insurance Companies in Emerging Markets \\ Prepared by Janet Kong and Manmohan Singh ${ }^{1}$ \\ Authorized for distribution by Jorge Roldos
}

May 2005

\begin{abstract}
This Working Paper should not be reported as representing the views of the IMF. The views expressed in this Working Paper are those of the author(s) and do not necessarily represent those of the IMF or IMF policy. Working Papers describe research in progress by the author(s) and are published to elicit comments and to further debate.

This paper focuses on asset allocation decisions of life insurance companies in emerging markets. Mature market insurers allocate only a small fraction of their assets to emerging markets because of regulatory constraints, rating pressures, and currency risk. However, global insurers invest directly in emerging markets by setting up subsidiaries rather than through portfolio investment, and this trend is increasing. Local insurers largely remain captive investors of local instruments and provide stability to the domestic securities market. The regulatory regime and the liquidity and depth of local markets play an important role in asset allocation decisions of insurers. Insurance companies are increasingly adopting asset liability management and risk control measures. However, insufficiently developed local markets and regulatory interventions on the liabilities side often limit optimal asset allocation.
\end{abstract}

JEL Classification Numbers: G22, G15, G18, G11, F37

Keywords: Insurance companies, emerging markets, asset allocation, investments Author(s) E-Mail Address: msingh@imf.org

\footnotetext{
${ }^{1}$ We thank Donald Mathieson and Jorge Roldos for their insightful comments, and Ivan Guerra for his able research assistance. Any remaining errors or omissions remain our own.
} 


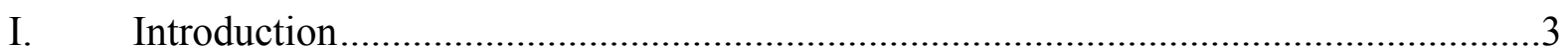

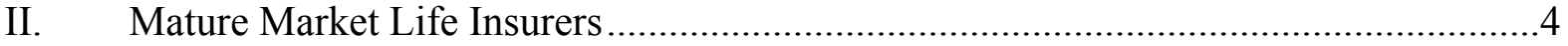

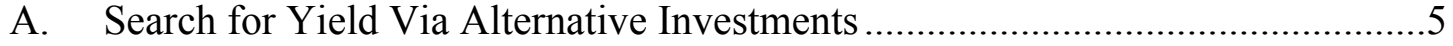

B. Stretegic Versus Tactical Asset Allocation Decisions.........................................6

C. Regulatory and Risk Management Constraints on Investing in Emerging Market Assets .......................................................................

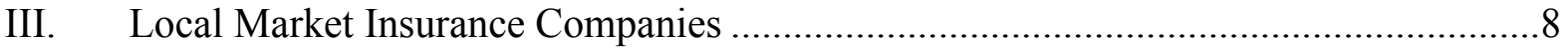

A. Asset-Liability Management ................................................................ 11

B. Regulatory Impact on Balance Sheets of Insurers ........................................14

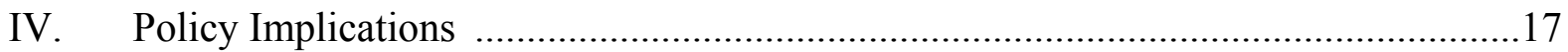

Tables

1. Total Emerging Market Bond and Equity Capitalization in the World, 2001 ..............5

2. Assets under Management by Insurance Companies...........................................

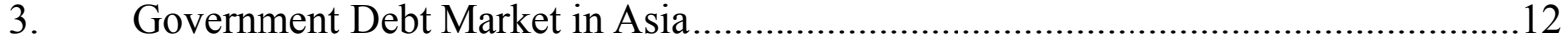

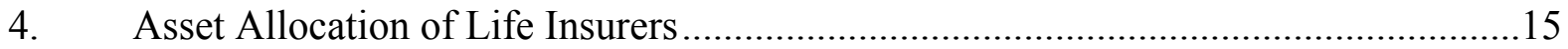

Figure

1. Asian Debt by Maturity by Currency Denomination...........................................12

Boxes

1. The Role of Insurance Companies during Emerging Market Volatility-

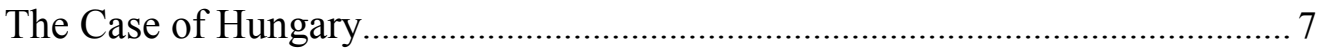

2. The Impact of Emerging Market Crises on Insurance Companies ............................10

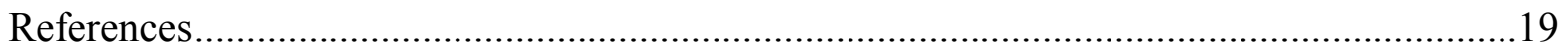




\section{INTRODUCTION}

Insurance companies are important financial intermediaries in both mature and emerging markets. In most mature market countries (with the exception of the United States and Canada), and in most parts of Asia and Central Europe, insurance companies are the largest institutional investors in terms of asset under management (AUM). In the United States, Canada and in most Latin American countries the largest institutional investors are pension funds. In Latin America, however, retirees have turned to insurers for annuity products when their defined contribution pension scheme matures, which is likely to boost the growth of the life insurance industry in the future (OECD, 2000). ${ }^{2}$

Given the nature of their liabilities, insurers are important conduits for providing long-term capital and their investment decisions could greatly affect capital flows to various asset classes. In particular, life insurers tend to be "buy-and-hold" investors. This paper will only focus on the life insurance industry as they are the main providers of long-term capital and their assets usually far exceed that of general insurers. The asset allocation of life insurers vis-à-vis emerging market assets, however, varies among the mature market insurers, global insurers with subsidiaries in local markets, and local insurers.

In general, mature market insurers allocate only a small fraction of assets to emerging markets due to a combination of factors such as rating pressure, regulatory constraints, and internal risk controls. Furthermore, to limit any currency mismatch, their asset allocation usually concentrates in foreign currency denominated emerging market assets. Overall, they don't play a major role in investing in emerging market assets.

Some global insurers have chosen to invest in emerging markets through direct investment by setting up subsidiaries rather than through portfolio investment. The presence of global insurers in local markets has been steadily increasing across all emerging markets as countries move to deregulate and liberalize their insurance industries. The subsidiaries of global insurers bring new products and new risk management skills to local market and become important investors in local instruments.

Local insurers are likely to remain large captive investors of a few local instruments thus providing some stability to emerging market assets. Life insurance tends to be a local business and require, the matching of local liabilities with local assets. However, lack of local instruments in many emerging markets may lead life insurers to increase their asset allocation towards foreign long-term instruments in the future, if permitted by regulations. Nevertheless, the aversion currency risk suggests that such investment would be rather limited.

\footnotetext{
${ }^{2}$ Chile is the only country with a matured defined contribution scheme currently but many reformed pension schemes in Latin America are expected to mature in the coming decade.
} 
Generally, insurance companies' asset allocation vis-à-vis emerging market securities depends on their size and geographical presence. Typically, there are three types of insurance companies: (i) insurers who operate primarily in mature markets (Pacific Life, Nippon Life, etc.); (ii) global insurers who are primarily domiciled in a mature market but have operations in emerging markets via subsidiaries (such as Allianz or ING); and (iii) local insurers that operate in one emerging market (such as PZU in Poland or LIC in India).

The regulatory regime and the state of development of the domestic capital market play important roles in the asset allocation decision of insurance companies, and affect their ability to conduct asset and liability management. ${ }^{3}$ In most emerging markets, shallow domestic capital markets and lack of long-term instruments have resulted in severe asset and liability mismatches. Restrictive investment regulations could also hinder portfolio diversification and efficient asset allocation by insurers. In some emerging markets (e.g., Hong Kong SAR and Singapore), there is little intervention on insurance product design and pricing and the industry has been flexible in managing its products and risks. Elsewhere, in countries where regulatory interventions in product pricing (e.g., minimum guaranteed return on products) have resulted in negative spreads for the insurers in the current environment of low interest rates, the industry's balance sheet has been weakened. Many regulators place localization requirement on the insurers' assets thereby making the insurers "dedicated" investors in local instruments.

This paper focuses primarily on asset allocation decisions of insurance companies subject to the institutional constraints faced by them. The paper also examines the cyclical and structural issues that affect the balance sheet of insurers and their asset allocation strategy vis-à-vis emerging market assets. In Section II, we discuss mature market insurance companies (including global insurers) and their constraints in investing in emerging market securities. Section III discusses the various factors affecting asset allocations of insurers in local markets. Policy implications are discussed in Section IV.

\section{MATURe MARKet Life InSURers}

In the United States and Western Europe, insurance companies without a global presence generally have portfolios biased towards investment grade fixed income products, and allocations to emerging markets typically do not exceed 5 percent of their portfolio. In other mature markets, such as Japan, the allocations to emerging markets are even less and do not exceed 1 percent of their total AUM. Insurers in the mature markets prefer a global asset allocation and their asset allocation usually impacts foreign currency-denominated emerging market assets. Market participants argue that in contrast to global insurance companies that have subsidiaries in emerging markets, mature market insurers often do not have the resources to do the necessary research to invest in emerging markets much less so to assess their currency risks. Portfolio allocation vary considerably; for instance in the United

\footnotetext{
${ }^{3}$ For a discussion on the importance of developing the local securities and derivatives markets in emerging markets please see Mathieson and Roldos (2003).
} 
Kingdom. there is a bias towards equity while continental Europe and the United States are biased towards fixed-income.

Table 1 illustrates that as of end 2001, total (i.e., international and local) emerging market debt was about $\$ 2$ trillion or about 5.9 percent of total world bond market capitalization. Total (i.e., international and local) emerging market equity was about $\$ 3.1$ trillion or, 11.4 percent of total world equity market capitalization. This would suggest that, as a rule of thumb, allocations that are less than 5 percent are far from a globally optimal portfolio.

However, insurers AUM (except in the United Kingdom) are biased towards the bond markets and thus are typically attracted only to the emerging market bonds, which represents below 6 percent of the total world bond markets. Since mature market insurers are least likely to hold sub-investment grade assets such as emerging-market debt, it is not surprising that insurers typically do not allocate more than 3-5 percent of their portfolios towards emergingmarket debt. ${ }^{4}$

\begin{tabular}{|c|c|c|c|c|c|}
\hline & Bond Ma & rkets & & Equity $\mathbf{N}$ & [arkets \\
\hline & (Million US\$) & $\%$ of World & & (Million US\$) & $\%$ of World \\
\hline Asia & $1,098,700$ & $3.1 \%$ & Asia & $1,997,577$ & $7.3 \%$ \\
\hline EasternEurope,MiddleEast,Africa & 694,300 & $2.0 \%$ & EasternEurope,MiddleEast,Africa & 521,829 & $1.9 \%$ \\
\hline Latin America & 284,500 & $0.8 \%$ & Latin America & 591,871 & $2.2 \%$ \\
\hline Total Emerging Markets & $\mathbf{2 , 0 7 7 , 5 0 0}$ & $5.9 \%$ & Total Emerging Markets & $3,111,277$ & $11.4 \%$ \\
\hline World Bond Markets & $35,101,200$ & $100.0 \%$ & World Equity Markets & $27,343,808$ & $100.0 \%$ \\
\hline \multicolumn{4}{|c|}{ Total Emerging Market Equity and Bond Capitalization } & \multicolumn{2}{|l|}{$5,188,777$} \\
\hline
\end{tabular}

Source: OECD, World Federation of Exchanges, 2001

\section{A. Search for Yield Via Alternative Investments}

The low interest rate environment of the past three years has led institutional and other investors to search for yields. In turn, this has meant that investors have started to look into non-traditional assets or alternative investments. However, the search for yield via alternative investments is constrained by the insurance companies' own ratings, which have been under pressure stemming primarily from the liability side of the balance sheet over the last couple of years. ${ }^{5}$ Also, some insurers do not classify emerging market assets as alternative investments but rather as international investments. Most European life insurance products offer policyholders a guaranteed minimum return and participation in investment results above the guaranteed rate. Guaranteed returns on life policies combined with the collapse in

\footnotetext{
${ }^{4}$ For global insurers with local subsidiaries and local insurance companies, the exposure to the local bond market is significantly higher as illustrated in Table 3, "Asset allocation of life insurers in EM."

${ }^{5}$ Ratings pressures, primarily stemming from the liability side of the balance sheet have been higher with reinsurance companies. Following Swiss Re's recent downgrade there are no standalone reinsurance companies with a triple-A rating.
} 
equity prices and the low interest rate environment, has led insurers to search for higher yields. Ratings pressure stemming from the balance sheet's liability side is keeping global insurers away from increasing allocation towards emerging markets. Credit losses from Enron and World-com defaults have been sizeable, and insurance companies' financial statements have not been very transparent about such losses. Market participants noted that pressures on ratings came from developments both in the asset and the liability side of the balance sheet in 2002, but that this year pressures derived mostly from the liability side (GFSR, 2003). In contrast, losses from emerging market investments have been small, even though insurers did not emerge totally unscathed from Argentina. Typically, credit losses have been mitigated by selling other bonds whose prices have risen in a declining interest rate environment. As a result of these losses, the insurance companies are keeping their allocations to emerging market assets stable.

\section{B. Strategic Versus Tactical Asset Allocation Decisions}

Global insurance companies with subsidiaries in local markets, in Central Europe and Latin America, tend to follow their insurance business strategy-i.e., issuance of local policies - and locally match their liabilities. In Central Europe, due to the EU convergence process, the local strategy is already harmonized with that of the parent company. However, in Asia, capital controls and other constraints may inhibit the local subsidiary to mimic their parent's business strategy. Generally, insurers invest in local securities and try to extend duration as much as possible in the local market, providing support to the development and stability of emerging market securities markets. For example, due to local regulations and currency controls (in Russia) local liabilities in dollars or dollar-linked debt may be matched by investment in non-local dollar bonds.

However, insurance companies that do not have operations in local markets do nevertheless invest a small fraction of their global portfolio in EM assets. While initially they used to do their allocations themselves, more recently they are outsourcing emerging market mandates to specialists. For example in Germany, medium and small-sized insurance companies in the mature markets that do not generally distribute their insurance policies in emerging markets, tend to perceive the asset class as an opportunity to diversify and enhance yields. Some of these companies have a higher share of their portfolio allocated to emerging market securities (up to 10 percent of total assets, compared to around 3-5 percent for the large ones), and although they buy-and-hold, some analysts suggest that they are more flexible and may be a less stable segment of the investor base.

Foreign investors' role in the local bond market could be sizeable, as illustrated by Hungary's local market turbulence in November 2003. Market participants suggest that insurers from Germany, Netherlands, France and Austria were the primary holders of about $€ 8$ billion in local Hungarian bonds. They had taken a one side bet in favor of convergence and could play against their own position; the market was relatively illiquid to unwind their large position (see Box 1). However, if such investors panic and sell at significant losses, the damage to the local markets could lead to a financial crisis. 


\section{Box 1. The Role of Insurance Companies during Emerging Market Volatility- The Case of Hungary}

In mid-October 2003, following positive growth data by the Board of Governors of the United States Federal Reserve system that led to a 30 bps increase in yields on Polish local bonds. Since the local bond markets of Poland and Hungary are correlated, the National Bank of Hungary (NBH) intervened heavily at the long end of the curve to cushion the losses arising from excess volatility and illiquidity stemming from the Polish debt markets. ${ }^{6} \mathrm{NBH}$ 's policy of simultaneously defending the exchange rate and the short-term interest rates (already the highest in the region at 9.5 percent) was achieved by surprisingly taking a pro-active role in the longer end of the local curve. Overnight inter-bank lending rates touched 10.5 percent; the deposit facility at NBH was reduced by 60 billion Hungarian forints (HUF), as commercial banks needed funding to finance their positions in the long end of the curve yielding about 8 percent. Market sources corroborate these views since a few hedge funds took heavy losses at the short end of the curve since they expected either an increase in the short-term rates or, a fall in the forint. ${ }^{7}$

Real money accounts from insurance companies from Germany, Netherlands and Austria have over $€ 8$ billion in local bonds and cannot play against their own position; the market is very illiquid to unwind such large position; de facto, they have a one side bet in favor of convergence. The convergence play continued to be associated by volatility stemming especially from hedge fund positions and NBH's inconsistent objectives. Local market sources indicate that a $€ 100$ million position from a hedge fund could impact the HUF by about 5 forints; typically the market becomes illiquid after the five primary dealers have quoted their $€ 20$ million bids each to a marginal $€ 100$ million.

Although the convergence play and the volatile environment do allow for roughly 200-300 bps yield enhancement, it is important to note that in due course, the foreign investor base, especially the insurers, may move elsewhere and may not be available once these countries join the EU. Experience from Greece and Ireland suggests that the authorities will need to support any budget deficits from a shrinking investor base as the convergence players and some of the local investor base will move elsewhere in the next 5 years. Poland and especially Hungary with large government bond markets have a lot to lose if this investor base disappears.

\section{Regulatory and Risk Management Constraints on Investing in Emerging Market Assets}

Guaranteed minimum returns may put pressure from the liability side of the business. In the recent low interest global environment, existing contracts have promised returns far in excess of the required guaranteed minimum, especially in Germany and the United Kingdom; however, in both countries, the new insurance policies that are now offered are at much lower returns. In the insurance industry, the actual returns to policyholders remain largely discretionary. Such payouts, that are not in line with the interest rate cycle or the business strategy, are possible since insurer's do not mark-to-market their assets. Such mismatch between actual pay-outs and accounting earnings has led some insurance companies to look for alternative investments that include credit-linked and principal protected notes (CLNs and PPNs) with a guaranteed pay-off to match their liability profile.

\footnotetext{
${ }^{6}$ Market sources estimate that NBH bought about 30 billion HUF ( $€ 11$ million) of 5 and 10 year bonds.

${ }^{7}$ Short-term interest rates were raised later and reached 13 percent towards end-November 2003.
} 
Alternative investments include structured products with investment grade ratings, such as those related to emerging market future flow receivables or CDOs (Collateralized Debt Obligations) and are considered to be promising avenues for investing in emerging markets. Some insurance companies have been investing in CDOs recently but still in very small amounts. They noted that adequately structured CDOs, with long lock-in periods that ameliorate redemption risks, have delivered annualized returns above the 20 percent level. The outstanding performance of some emerging market CDOs compared to the (relatively) poor performance of High Yield CDOs has attracted the attention of both the U.S. and European insurers.

In mature markets, the larger insurers (including the global companies) usually adopt risk management methods that include value-at-risk (VAR), net-asset valuation (NAV), stress tests and scenario analysis, loss limit and cumulative global credit risk (Munich Re, 2002). ${ }^{8}$ The smaller insurance companies are likely to out-source such functions.

Sub-investment grade assets and impaired assets, as well as credit default swaps (CDS), are costly for insurance companies to hold. According to some mature market insurers' internal policies, once an asset is rated single B, every effort is made to sell the asset since regulations require allocating 100 percent capital towards non-performing assets. As long as the asset is kept on the books, this "set aside" capital is permanently impaired even if the asset recovers (for example, after a debt restructuring or a work-out) to a secondary market price of say 80 or 90 cents on the dollar. Insurance companies have been involved in CDS transactions but they pointed out that the fact that CDS have to be marked-to-market while bonds do not, has reduced the relative attractiveness of CDS.

Market sources indicate that impaired assets held by insurance companies are a trivial fraction of their overall portfolio. For example, in the United States, distressed assets largely stem from the U.S. high yield market (and usually not from emerging markets) and are not the result of a deliberate asset allocation but a reclassification of formerly-performing assets.

\section{LoCAL MARKet InSURANCE COMPANiES}

In emerging Asia and Europe, where insurance instruments are also used for traditional retirement saving purposes, insurance companies are the largest institutional investors (Table 2). ${ }^{9}$ In Latin America, however, pension funds are the more dominant institutional investor, while insurance penetration remains low. The growth of pension funds has nevertheless contributed to the expansion of the life insurance sector, in particular with a sharp rise in the sale of annuities (see Garcia-Cantera and others, 2001). The growth of annuities markets has not been restricted to privatized systems, and Singapore has also

\footnotetext{
${ }^{8}$ Typically, stress testing would show impact on the balance sheet of up to a 100 basis point move in global interest rates and up to $\mathrm{a}+/-30$ percent change in the relevant equity market.

${ }^{9}$ In countries where insurance products are also used for savings purposes, the products tend to have a savings component in addition to the standard term life insurance.
} 
witnessed a rapid growth in recent years, as a result of the reform of regulations governing withdrawals from the Central Provident Fund (MacKenzie, 2002). Asset under management Table 2. Assets under Management by Insurance Companies (In percent of GDP, both life and general insurers uniess noted)

\begin{tabular}{lrrrrr} 
& $\mathbf{1 9 9 8}$ & $\mathbf{1 9 9 9}$ & $\mathbf{2 0 0 0}$ & $\mathbf{2 0 0 1}$ & $\mathbf{2 0 0 2}$ \\
\hline Asia & & & & & \\
Korea & 25.8 & 29.4 & 30.2 & 34.0 & 35.8 \\
Malaysia & 13.6 & 15.1 & 14.9 & 20.5 & 21.0 \\
Philippines & 3.5 & 3.7 & 3.8 & 3.7 & 4.0 \\
Singapore & 18.5 & 23.3 & 24.4 & 34.1 & 37.6 \\
Thailand & 5.8 & 6.5 & 6.6 & 7.6 & 8.3 \\
& & & & & \\
Eastern Europe, Middle East, & Africa & & & & \\
Hungary & 3.3 & 3.9 & 4.2 & 4.5 & 3.8 \\
Poland 1/ & 3.0 & 3.6 & 4.3 & 5.0 & 6.0 \\
Turkey & 1.1 & 1.6 & 1.5 & 1.5 & n.a. \\
South Africa 1/ & & & & 74.4 & 68.7 \\
& & & & & \\
Latin America & & & & & \\
Argentina & 1.8 & 2.3 & 2.7 & 3.2 & 4.6 \\
Brazil & n.a. & 2.1 & 2.6 & 2.6 & 2.8 \\
Chile & 14.4 & 17.1 & 18.6 & 19.2 & 19.9 \\
Colombia & 0.8 & 0.8 & 0.8 & 0.9 & 1.0 \\
Mexico & 1.4 & 1.4 & 1.3 & 1.5 & 1.7 \\
Peru & na & na & na & 2.0 & 2.2 \\
\hline I L & & & & & \\
\hline
\end{tabular}

$1 /$ Life insurers only

Sources: National regulators; and IMIF staff estimates

of insurers in emerging markets continue to grow despite the 1997/98 financial crisis (see Box 2 for an analysis on the impact of financial crisis on insurers). With the rapid expansion of their balance sheets, insurers increasingly rely on investment returns to meet future obligations towards policyholders as well as generating surpluses for shareholders.

The investment decisions of life insurance companies operating in emerging markets depend on the regulatory constraints, the development of local capital markets, and risk management guidelines. In making asset allocation decisions, insurers must choose the optimal asset mix by making strategic and tactical allocation among instruments permitted by investment restrictions and internal risk control guidelines, and by matching asset and liabilities so as to minimize the impact of adverse market developments on the balance sheet. In most emerging market economies, insurers are required to maintain local assets to match local liabilities. ${ }^{10}$ Thus most local insurance asset are invested in local capital markets. At the same time, regulations put strict limits on various instruments, which usually favor fixed-income instruments over equity. In addition, even when investment regulations are not binding, insurers are constrained by the lack of alternative instruments and illiquidity of local markets thereby suffering from asset and liability mismatches.

\footnotetext{
${ }^{10}$ The "localization" requirement is intended for policyholder protection in cases of insurer's bankruptcy so that assets are held locally and can be used to compensate the policyholders. Hong Kong SAR is an exception; the Office of the Commissioner of Insurance is evaluating the current regulation on investment with a view to strengthen asset valuation and safeguard policyholder assets in the future.
} 


\section{Box 2. The Impact of Emerging Market Crises on Insurance Companies}

Financial crises worsen the operating results and balance sheets of most financial intermediaries, but the effects are particularly severe for insurance companies. A financial crisis is usually accompanied by a sharp decline in output, a massive devaluation, increasing inflation and interest rates, and a collapse in asset values. The consequences of these drastic economic changes for the insurance industry are manifold: demand for insurance products drops, resulting in lower premiums and a rise in early terminations of existing contracts; claims increase due to higher inflation and an adverse environment; insurers' assets decline in value; and rising inflation requires higher reserve on the liability side. Thus, a financial crisis poses a major threat to the solvency and liquidity of the insurance industry.

This has become rather clear after recent emerging market crises, as noted in a recent study by Swiss Re (2003). Life insurers suffered not only from a decline in new business, but also from an increase in lapses - nonpayment of premiums on existing life products. As the Table shows, new business collapsed during the year of the crisis and lapse ratios increased by almost three-fold in the year after the crisis. In Argentina, probably due to the expectation of a future crisis, the lapse ratio steadily increased beginning two years before the crisis. Savings type policies were the most sensitive to changes in income and wealth and thus experienced the most pronounced decline in premiums. The increase in lapses was more significant in Indonesia and Argentina, where a majority of life products were denominated in U.S. dollars. In Argentina, contracts with a savings component were mostly cancelled once the parity was broke and the majority of new products sold after the crisis were one-year local-currency denominated pure insurance products - a major setback to a once sophisticated insurance market. Balance sheet pressure threaten the solvency of many insurers and sometimes lead to a costly restructuring process. Virtually all local assets lost in value, and claims were higher, which required higher reserves relative to premiums. Equity relative to capital declined. Thus, solvency, measured as the capital-to-reserve and the capital-to-premium ratio, was in question. Furthermore, insufficient asset and liability management that led to large asset-liability mismatches for the life insurers and poor risk management practices have aggravated the adverse impact and resulted in a few bankruptcies, as in Korea.

The crises hit local and foreign insurers alike, but the latter were generally better equipped to withstand episodes of financial crisis. First, foreign insurers' better-diversified investment portfolio and more sophisticated asset and liability management helped them to weather the financial storm. Second, they could always rely on additional capital from the parent company to shore up the balance sheet. As a result, in a few countries, such as Mexico, Indonesia, and Thailand, foreign insurers picked up market share after the crisis. To remain liquid and solvent through a financial crisis, insurers need to protect their balance sheets and design products that can cope with a volatile environment. Proper asset and liability management is the key to maintaining a strong balance sheet, while creating a well-diversified portfolio and buying reinsurance to transfer away part of the risk are also beneficial. As the insurer's ability to conduct asset and liability management is constrained by the development of local capital markets as well as regulatory limits, a few countries recently have relaxed the investment regulations. From the liability side, insurers could move away from guaranteed benefits to unit linked products to reduce the investment risk.

$\begin{array}{llllll} & \text { T-2 } & \text { T-1 } & \text { T } & \text { T+1 } & \text { T+2 } \\ \begin{array}{l}\text { New business, \% change (yoy) } \\ \text { Indonesia }\end{array} & 25.4 & 21.6 & -12.6 & 0.9 & 34.4 \\ \text { Thailand } & 10.1 & -16.3 & -29.1 & 37.9 & 40.5 \\ & & & & & \\ \text { Lapse ratio, in \% } & 3.7 & 2.6 & 5.5 & 12.8 & 7.9 \\ \begin{array}{l}\text { Indonesia } \\ \text { Thailand }\end{array} & 3.2 & 3.4 & 5.4 & 9.2 & 8.3 \\ \text { Argentina } & 9.6 & 15.4 & 31.3 & & \end{array}$

Source: Swiss Re, Sigma No. 7/2003.

T: refers to the year of the financial crisis, $=1998$ for Indonesia and Thailand, and 2002 for Argentina. 
Consequently, most life insurers are major investors in local capital markets and will likely remain so in the future. Duration gaps, resulting from asset and liability mismatches are prevalent in all emerging markets. ${ }^{11}$ Furthermore, insurers in many countries face tradeoff between yield enhancement and asset and liability management (ALM), due to limited guidelines on ALM.

\section{A. Asset-Liability Management}

ALM gained popularity in mature markets since the mid-1980s, when interest rates became relatively volatile. The key to ALM lies in segmentation of the liability side according to the differing investment requirements on the assets, regarding the composition of maturities and liquidity needs, i.e., duration (Wright 1991). Therefore, ALM typically implies controlling the balance sheet exposure to interest rate risk via duration match.

Increasingly in emerging markets, insurers also have begun to use ALM principles and risk management tools in making investment decisions. However, insufficiently developed local capital markets can limit the investment choices and hinder ALM. Moreover, lack of expertise in risk management and insufficient guidance on ALM could mean that asset allocation may deviate from a desirable combination.

In most emerging market economies, the biggest hurdle to ALM is the lack of long-term fixed-income instruments and relative illiquidity in bond and equity markets (Figure 1). ${ }^{12}$ In Korea, for example, a typical life insurer's liability has an average duration of over 10 years, while the average duration of its assets is only $3 \frac{1}{2}$ years. Similar duration gaps exist in other emerging market countries. Faced with such a gap, insurers have relatively few options to increase asset duration. Most strive to invest in the long-end of the local fixed-income market. As a result, in countries like Thailand, Singapore, Poland, Hungary, insurance companies are the largest investors in the 10-year segment of the local bond market. According to some market estimates, in Hungary, the two largest insurance companies hold around 75 percent of the 10-year benchmark bond. While insurers provide stable demand for the local long-bond, they also reduce liquidity in the secondary market due to their buy-andhold behavior. Table 3 shows that, with the exception of Hong Kong SAR, most government bond markets in Asia have relatively low turnover ratios. Illiquidity affects ALM by making portfolio adjustment costly. In Singapore, lack of liquidity and depth in the local equity market is also cited as a reason for difficulty in managing assets and the strong bias for fixed income instruments.

\footnotetext{
${ }^{11}$ Duration measures the interest rate sensitivity of assets and liabilities. A duration gap between assets and liabilities indicates that the balance sheet could be adversely or favorably affected by movements in interest rate, depending on the sign of the gap and the direction of the interest rate change.

${ }^{12}$ Even in mature markets, perfect ALM is difficult to achieve, despite the availability of more financial instruments.
} 
Figure 1. Asian Debt by Maturity by Currency Denomination
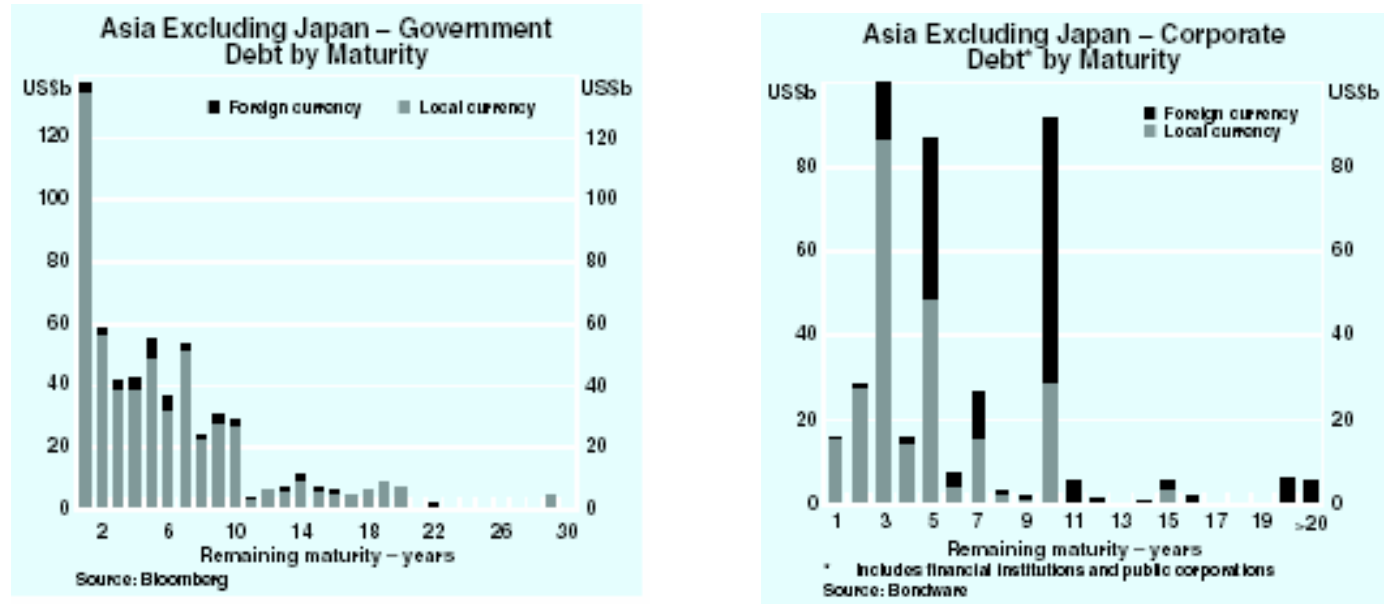

Table 3. Government Debt Market in Asia

\begin{tabular}{lccc}
\hline & Turnover Ratio 1/ & Futures Market & Repo agreement \\
\hline China & 0.4 & Yes & Yes \\
$\begin{array}{l}\text { Hong Kong SAR } \\
\text { Indonesia }\end{array}$ & 15.6 & & Yes \\
Korea & 6.5 & Yes & \\
$\begin{array}{l}\text { Malaysia } \\
\text { Philippines }\end{array}$ & 3.7 & Yes & Yes \\
Singapore & 5.0 & & Yes \\
Taiwan & & & \\
Thailand & 2.5 & & \\
\hline
\end{tabular}

Source: Reserve Bank of Australia Bulletin (2003);

$1 /$ Measured as a share of annual bond turnover of securities outstanding, as of 2002.; for Korea, turnover ratio increased to 7.6 (2003) and 8.6 (2004)

Paucity of derivatives, such as interest rate swaps, swaptions, caps, floors, and currency swaps, also constrains ALM activities. In countries where investment in foreign securities is allowed, such as Singapore, Korea, Hong Kong SAR, Poland, and Hungary, insurers could invest (up to regulatory limits) overseas to pick up the duration. However, the cost associated with hedging and the lack of long-duration currency swaps inhibits the search for duration overseas. Without these derivative products, rebalancing for ALM can only be achieved through outright sale and purchase of cash instruments, which can be costly.

Many insurers thus choose to manage the duration through the liability side by repricing existing products and offering new products that are of lesser duration. Unit-linked products 
are gaining popularity in many South-East Asian and Central and Eastern European countries. ${ }^{13}$ While in Thailand, such products are not yet allowed by the regulators, unit-linked products are available in Singapore, Korea, Hong Kong SAR, Indonesia, Malaysia, Poland, and Hungary. In Hungary, for example, two thirds of the new life insurance contracts are unitlinked products. In Poland, one third of life insurance products are unit-linked (Dorfman and Ennsfellner 2002). These products usually carry a low minimum return with a "bonus" component depending on the equity market performance. The existence of the "bonus" effectively lowers the duration of the liability. By some estimates, a 20-year unit-linked life product has an effective duration of only 6 years. The emergence of unit-linked life products has transferred some asset risk to the policyholders and thus facilitates ALM; however, such products pose certain competitive pressure on the mutual fund industry where traditional products carry no minimum return at all.

Another element of ALM involves limiting currency risks. In a number of Latin American countries, including Mexico and Argentina, a significant share of life insurance contracts are specified in foreign currency, usually in US dollars. ${ }^{14}$ This "dollarization" of liabilities is probably a consequence of the region's history of hyperinflation and exchange rate volatility. To contain foreign exchange risks, for instance, Mexican regulators require that dollar-linked liabilities be matched with dollar-linked assets. As a result, local insurance companies are one of the largest holders of sovereign dollar-denominated external debts (see Oswald and Sekiguchi, 2002). Although this offers significant support for these instruments, external diversification for the Mexican insurance industry is limited to portfolio investments in foreign-currency-denominated securities issued by Mexican entities. ${ }^{15}$ In contrast, Colombia's regulations do not have formal guidelines on ALM. Nevertheless, even local insurance companies hold more than 20 percent their assets in foreign-currency-denominated assets. Unlike the case of Mexico, Colombian insurance companies can invest in foreign currency debt instruments of any sovereign or corporate that is investment grade.

In many emerging market countries regulations do not provide specific guidance on ALM. While subsidiaries of global insurance companies in emerging markets normally have to adhere to internal risk control guidelines on ALM, their local counterparts usually lack such expertise and guidance. Therefore, some local insurers seek yield enhancement at the expense

\footnotetext{
${ }^{13}$ Unit-linked products are a form of variable life insurance products that combine insurance with an investment component. Usually the products carry a minimum return and in addition a "bonus" that varies with market movements. The appeal of this type of insurance product is that the policy holders can benefit in a transparent way from the higher than average long-term returns on the equity markets while, at the same time, retaining the advantages of life insurance products.

${ }^{14}$ Hong Kong SAR also has some US dollar denominated insurance contracts. However, due to the credible currency board, no regulatory restriction is put on the asset side. The appointed actuary has the full discretion in deciding the optimal asset allocation following the prudent person rule.

${ }^{15}$ Insurance companies in Mexico are allowed to use derivatives for currency-asset-liability matching purposes, but in practice they rarely use them.
} 
of ALM. For example, in Hungary, during the recent turmoil in the local bond market that sent short-term interest rates soaring, most subsidiaries of global insurers had to continue investing in the long end of the yield curve to minimize the duration gap. However, their local counterparts could go to the short-end of the curve for yield pickup at the expense of enlarging the duration gap. In Korea, insurers also reportedly face a tradeoff between yield enhancement and ALM. When solvency requirements only account for underwriting risk, asset-liability mismatch does not cost the insurer in terms of statutory capital. Market participants coin this as "free risk." In the past, United States and Canadian life insurers faced similar situations, when competitive pressure drove the insurance companies to mismatch asset and liabilities seeking higher returns by assuming higher credit risk (Briys and de Varenne 1996). A large number of insurance companies failed in the United States in the late 1980s and early 1990s; a few in Canada also went under in early 1990s. These failures eventually led to changes in U.S. and Canadian insurance regulations in the mid-1990s.

\section{B. Regulatory Impact on Balance Sheets of Insurers}

Insurers carry multiple risks through their business operation. The main risks on their balance sheet can be classified as: (i) investment risks, (ii) underwriting risks, and (iii) asset/liability matching risks (Babbel 1996). For policyholder's protection, most regulations focus on controlling the three types of risks through solvency margin requirement and investment regulations. ${ }^{16}$ Thus in the insurance business, insurers are usually guided by the local regulation in addition to their internal risk controls.

Most emerging market economies have adopted solvency requirements for insurance companies that are based on or similar to those of the European Union (EU) Directives (OECD, 2001). A few countries, including Singapore, Indonesia, Malaysia, and also Taiwan Province of China have adopted risk based capital (RBC) regime that is similar to the U.S. and Japanese system. Under the European system, only underwriting risk is included in the calculation of the solvency requirement, while the U.S. and Japanese systems explicitly accounts for investment and asset and liability mismatching risks in addition to the underwriting risk. Given the growing importance of investment risks, many have argued that the European system does not adequately address the risks in insurance operation. ${ }^{17}$ Under the European system, investment risks are controlled by means of investment regulations on a particular investment, asset class or region. Consequently, regulators in many emerging market economies prescribe specific investments as well as the percentage of their assets that insurers are permitted to invest in each. ${ }^{18}$

\footnotetext{
${ }^{16}$ Solvency margin requirement puts a floor on the statutory capital of the insurers, which serves as a buffer to ensure that obligations under insurance contracts can be met at any time and that insurers have enough free financial means at its disposal in order to absorb the difference between actual and projected profits and expenses.

${ }^{17}$ A quantitative comparison of the two sets of regulations suggests that the U.S. RBC system produces higher capital requirement for U.S. insurers than under the European system (Swiss Re 2000).

${ }^{18}$ Hong Kong SAR has relied on industry self-regulation and prudent person rule on investment.
} 
These investment restrictions play a major role in shaping the portfolio of insurance companies. Table 4 shows the industry asset allocation for life insurers in various emerging market economies. With the exception of Hong Kong SAR, South Africa, and to some degree Singapore, most countries have a strong bias for fixed-income instruments, since many regulations explicitly limit the investment in equity and real estate and prohibit investment in foreign instruments. These stringent investment guidelines may not only constrain the insurance companies' asset allocation but also affect their insurance costs, as a well-diversified investment portfolio can help to reduce interest rate and market risks.

Table 4. Asset Allocation of Life Insurers (as of end of 2002 unless otherwise noted) (In percent of total)

\begin{tabular}{|c|c|c|c|c|c|c|c|c|}
\hline & $\begin{array}{c}\text { Cash \& } \\
\text { Deposits }\end{array}$ & Equities & Bonds & $\begin{array}{c}\text { Foreign } \\
\text { Securities }\end{array}$ & Loans & Real Estate & Other & Total \\
\hline \multicolumn{9}{|l|}{ Asia } \\
\hline Hong Kong SAR ${ }^{1}$ & 7 & 35 & 38 & 0 & 0 & 0 & 20 & 100 \\
\hline Korea & 2 & 7.5 & 29.8 & 6.2 & 26.5 & 5.5 & 22.5 & 100 \\
\hline Malaysia & 29 & 0 & 53 & 0 & 9 & 4 & 4 & 100 \\
\hline Philippines & 12 & 16 & 52 & & 4 & 16 & 1 & 100 \\
\hline Singapore (overall) & 8 & 3 & 52 & 21 & 10 & 5 & 1 & 100 \\
\hline Singapore (unit-linked) & 6 & 63 & 30 & 0 & 0 & 0 & 2 & 100 \\
\hline Thailand & 8 & 9 & 64 & 0 & 11 & 3 & 5 & 100 \\
\hline \multicolumn{9}{|c|}{ Eastern Europe, Middle East, Africa } \\
\hline Hungary & 3 & 5 & 91 & 0 & 0 & 0 & 0 & 100 \\
\hline Poland & 4 & 11 & 83 & 0 & 0 & 1 & 0 & 100 \\
\hline South Africa & 7 & 48 & 15 & 14 & 0 & 5 & 10 & 100 \\
\hline \multicolumn{9}{|l|}{ Latin America } \\
\hline Argentina & 22 & 9 & 61 & 0 & 1 & 4 & 3 & 100 \\
\hline Brazil & 1 & 5 & 64 & 0 & 6 & 5 & 18 & 100 \\
\hline Chile & 3 & 14 & 51 & 2 & 20 & 7 & 2 & 100 \\
\hline Colombia & 3 & 11 & 68 & 7 & 8 & 3 & 0 & 100 \\
\hline Mexico & 2 & 6 & 80 & 0 & 3 & 7 & 3 & 100 \\
\hline Peru & 21 & 17 & 43 & 0 & 0 & 0 & 19 & 100 \\
\hline
\end{tabular}

Sources: National insurance regulators; and IMF staff estimates.

1/ Data for Hong Kong SAR are for the year 2000/2001.

Furthermore, regulatory interventions on the liability side could have an unintended impact on asset allocation as well. In many countries regulators intervene in product design and pricing by dictating a minimum guaranteed return on insurance products. A few countries, Thailand, Croatia, and Korea reportedly have guaranteed returns higher than the market rate. ${ }^{19}$ In addition, competitive pressure in some countries has also led to underpricing of the insurance products to generate returns above the required minimum to gain market share. ${ }^{20}$ These

${ }^{19}$ In Korea, products with fixed interest rate were largely popular under the high interest rate base of the past, but recently sale of such products is dropping; thus guaranteed rate has also dropped.

${ }^{20}$ Similar practices exist in mature markets such as Germany and the United Kingdom 
anomalies in conjunction with the recent global low interest rate environment resulted in negative spreads, i.e., higher returns on liabilities than on assets, for the industry, and adversely affected the solvency of some insurers in Germany, the United Kingdom., Central and Eastern Europe, and Asia. ${ }^{21}$ For example in Thailand, policyholders are not only given a guaranteed return at maturity but also guaranteed surrender value. During a rising interest rate environment, customers with products that are locked at guaranteed returns below the current market rate could simply cash out with the guaranteed surrender value and shop for better rates. This could force the insurers selling their bond portfolio at a loss. In a declining rate environment, many insurers have to re-calculate their liabilities on the historical products that were offered at high guaranteed return with a lower discount rate. This re-calculation has reportedly caused many insurers to raise reserve to meet solvency requirement, which again could lead to undesirable portfolio adjustments.

As with mature market and global insurers, widespread negative spreads and the nature of the regulation have led many insurers to search for higher yields. In recent years, some insurers (especially in Asia) have invested in structured credit products such as synthetic emerging market CDOs, CLNs and asset backed securities for yield pickup. Also, wherever allowed by regulations, investments in project loans and in private placement have reportedly increased in many emerging markets. In certain parts of Asia, some insurers have also provided guarantees on principal-guaranteed products offered by banks, in order to earn an upfront fee,. Some have opted for an absolute return investing strategy at the expense of duration gap.

Interestingly most life insurers in emerging markets are not taking advantage of a method of yield enhancement that is commonly used in mature markets, such as lending its securities for reverse repo operations. ${ }^{22}$ In some countries, the law on security lending is not in place, thus reverse repo is not a viable option. However, in quite a few countries, such as Hungary, Poland, Singapore and Hong Kong SAR, where securities lending and reverse repo are permissible for insurers, it is rather under utilized.

Insurance regulations do not require marking-to-market assets on a daily basis and usually liabilities are not marked-to-market at all, thereby differentiating insurers from other institutional investors. While in most countries valuation principles prescribe the marking of assets to market, the reporting for insurers is usually on quarterly basis (Dickinson, 2000). Thus, insurers can at times "sit through" market turbulence thus providing stability to the

\footnotetext{
${ }^{21}$ For a discussion on how guaranteed products affect mature market insurers see GFSR (March 2004).

${ }^{22}$ Reverse Repo refers to reverse repurchase agreement, the opposite of a repo-an immediate purchase of securities and a simultaneous agreement to resell these securities at a later date. A reverse repurchase agreement is typically conducted between a party that needs to borrow a particular security and a counterparty that wishes to augment the returns on its securities portfolio.
} 
market. $^{23}$ This perhaps makes them a more stable investor. Furthermore, most insurers are not benchmarked against any particular index, so the risk of "herding" with other investors during drastic market swings is mitigated. On the other hand, most regulations only provide for using market value for the asset but not for the liabilities. Though desirable in principal, the asymmetric mark-to-market requirement on the two sides of the balance sheet could have undesirable consequences. For example, in certain countries, it was reported that during the recent global equity market downturn, many insurers suffered losses on their investment in equities. While their liabilities that are linked to equity market performance would have been correspondingly lower, the regulation does not provide for recalculating the liabilities based on the market value. Consequently, for some insurers, it appeared that they had insufficient capital due to the decline in their asset and in order to raise capital to meet the solvency requirement some had to sell equities in a falling market. ${ }^{24}$

\section{Policy IMPLications}

Developing local securities markets is critical for the insurance industry to properly manage its risks and provide financial intermediation. The lack of long-dated bonds and derivatives presents challenges to insurers across the emerging markets. Many have argued that the first step governments can take to help the industry is to begin issuing long-duration bonds and extend yield curves beyond the mid-range.

Global insurers that operate in emerging markets and are bound by their internal risk guidelines view that insurance regulations in most emerging markets do not appropriately account for investment risks inherent in their operations. Quantitative limits on investments often lead to homogenous asset allocation when the domestic capital market is not well developed. Furthermore, stringent investment restrictions do not necessarily help to reduce the investment risk and could even increase the cost of insurance. Market participants suggest that investment regulations should incorporate measures of investment risk and duration, or alternatively that a $\mathrm{RBC}$ regime can be adopted with the prudent person rule on investment (Kwon, 2001).

With appropriate regulation that safeguards the solvency of the insurers, insurance companies could become a stable long-term investor in local instruments. Furthermore, their ALM needs could stimulate the development of local capital markets by offering new insurance products and demanding new financial instruments for hedging and risk management purposes.

However, the rapid growth of the life insurance industry in emerging markets in the absence of comparable development of the local capital market could also have some unintended consequences. The sizeable amount of AUM by insurers will compete for (relatively) limited

\footnotetext{
${ }^{23}$ Some insurers report the use of internal risk management, which requires assets to be marked-to-market on daily basis. However, as long as the valuation movement does not violate the prudential limits set internally, the need to adjust asset allocation can be avoided.

${ }^{24}$ In mature markets, asymmetric marking-to-market also presents similar challenges.
} 
long-term instruments. Some market participants noted that, as with rapidly growing pension funds, this could lead to excessive market volatility, underpricing of credit risk, and potentially asset price bubbles. 


\section{REFERENCES}

Babbel, David, and Anthony Santomero, 1996, "Risk Management by Insurers: An Analysis of the Process," The Wharton Financial Institutions Center Working Paper No. 96-16 (Philadelphia: The Wharton School, University of Pennsylvania).

Briys, E., and F. de Varenne, 1996, "On the Risk of Life Insurance Liabilities: Debunking Some Common Pitfalls," The Wharton Financial Institutions Center Working Paper No. 96-29 (Philadelphia: The Wharton School, University of Pennsylvania).

Dickinson, Gerry, 2002, “The Search for an International Accounting Standard for Insurance: Report to the Accounting Task Force of the Geneva Association," The Geneva Papers on Risk and Insurance, Vol. 28, No. 2, pp. 151-75.

Dorfman, Mark, and Karl Ennsfellner, 2002, "Insurance in Transition Economies: Poland, Czech Republic, and Hungary," International Insurance Foundation Occasional Paper No. 5 (Washington).

Garcia-Cantera, José, Steve Faucher, Flavia Montoro, and Laura Molina, 2002, "Private Pension Funds in Latin America," in Equity Research: Latin America, Salomon Smith Barney, (December).

International Monetary Fund, 2002, Global Financial Stability Report, World Economic and Financial Surveys (Washington), September.

—_, 2003, Global Financial Stability Report, World Economic and Financial Surveys (Washington), September.

Kwon, W., 2001, "Toward Free Trade in Services: The ASEAN Insurance Market," International Insurance Foundation Occasional Paper No. 3 (Washington).

MacKenzie, Sandy, 2002, "The Role of Private Sector Annuities Markets in an Individual Accounts Reform of a Public Pension Plan," IMF Working Paper No. 02/161 (Washington: International Monetary Fund).

Mathieson, Donald J., Jorge E. Roldos, Ramana Ramaswamy, and Anna Ilyina, 2004, Emerging Local Securities and Derivatives Markets, World Economic and Financial Surveys (Washington: International Monetary Fund).

Munich Re Group, 2002, Annual Report, pp. 167-9.

OECD, 2000, “Institutional Investors in Latin America," (Paris: Organization for Economic Cooperation and Development). 
— , 2001, "Insurance Regulation and Supervision in Asia and Latin America," (Paris: Organization for Economic Cooperation and Development).

Oswald, William, and David Sekiguchi, 2002, "Mexico's Local Markets" in Global Markets Research, Emerging Markets (New York: Deutsche Bank).

Reactions, 2002, Triple-A Ratings_-A Dying Breed? (November).

Swiss Re, 2000, "Solvency of Non-Life Insurers: Balancing Security and Profitability Expectations," Publication Brief No. 1/2000. 